\title{
CHARACTERISTICS OF FISH OIL PRODUCED THROUGH MADIDIHANG FISHMEAL INDUSTRY WASTE TREATMENT (THUNNUS ALBACARES) USING ADSORBENTS
}

\author{
Budiadnyani I Gusti Ayu* \\ Marine and Fisheries Polytechnic Jembrana, Indonesia \\ Harsanto Soni, Ismail Ece Gofar \\ Marine and Fisheries Polytechnic Sidoarjo, Indonesia \\ *E-mail: igustiayu678@gmail.com
}

\begin{abstract}
Tuna fishmeal industrial waste is largely fish oil. Tuna oil is a source of polyunsaturated acid (PUFA), especially omega-3 fatty acids namely docosahexaenoic acid (DHA, C22: $6 \Omega-3$ ) and eicosapentaenoic acid (EPA, C20: $5 \Omega-3$ ). This study examined the administration of different types and concentrations of adsorbents utilized in the tuna fishmeal industry waste treatment. The study was designed utilizing 2 factorial complete random designs, namely adsorbent types (bentonite, zeolite and activated charcoal) and adsorbent concentrations $(5 \%, 10 \%$, and $15 \%)$. Parameters analyzed were clarity (L value), free fatty acids (ALB) and peroxide value. Analysis of fatty acids composition was carried out on fish oil with the best treatment. The analysis results exhibited that the interaction between adsorbent type and concentrations had a significant effect on the level of clarity ( $L$ value) and the amount of peroxide oil in the bleached fish, and had no significant effect on free fatty acid levels (ALB). The calculation result of the best treatment of tuna byproducts is the $10 \%$ zeolite concentration. It exhibited a clarity value of 36.50 , acid value $0.25 \mathrm{mg} \mathrm{KOH} / \mathrm{g}$, ALB content $0.17 \%$ (oleic), and peroxide value $2.12 \mathrm{meq} / \mathrm{kg}$. Zeolite has a highly structured pore, and the composition of Si/Al represents an active surface capable to be in contact with degradation compounds in fish oil. The composition of fatty acids from the byproducts oils of the post-treatment tuna fishmeal exhibits increased EPA by $12.03 \%$ and DHA by $18.25 \%$. However, unsaturated fatty acids exhibited a decrease. SFA decreased by $36.19 \%$, MUFA by $29.73 \%$, and PUFA by $34.08 \%$. The total unsaturated fatty acids (MUFA + PUFA) were $63.81 \%$.
\end{abstract}

\section{KEY WORDS}

Treatment, adsorbent, tuna oil, EPA, DHA.

Indonesia is one of the countries with the highest tuna potential in the world. The total tuna production reaches 613575 tons per year, valued at IDR 6.3 Trillion (Dimas, 2014). Indonesia produces and processes tuna through the fishmeal industry. Canned tuna exports reached 2.149.546 tons. Based on the Sorong City Maritime and Fisheries Service Office in 2013, the total canned tuna export was 2950 tons. The tuna fishmeal industry produces 28.000 tons of waste annually (Irianto, 2007). The waste is in the form of solid and liquid waste. Solid waste is heads, scales, and stomach contents. On the other hand, the liquid waste is generally byproduct oils (Purnomo, 2005). Solid waste is then processed into fish meal. The waste treatment produces liquid waste in the form of by-product oil (Estiasih, 2009).

The byproducts of miling process contain a high content of omega- 3 fatty acids at $27.20 \%$ (Howe et al, 2007). The omega 3 fatty acid was produced from $11.33 \%$ fish heads, $18.89 \%$ skin, and $16.42 \%$ stomach content (Toisuta et al., 2014). Omega-3 fatty acids in fish oil are beneficial to health (Aidos, 2002). DHA is a $\omega-3$ fatty acid. Its main function nourishes the brain (Innis, 2007; McNamara, 2010) and eyes (Wiedemann et al., 2004). These fatty acids play an important role in shaping brain cell structure, the nervous system (Lukiw and Bazan, 2008), and improving memory (Hasio et al., 2008; Chung et al., 2008). 
Fish oil derived from the industrial byproduct contains high-level non-oil material impurities, phosphatides, dark colors, free fatty acids, and peroxide. These decreases the byproduct oil quality below fish oil quality standard (Wardhani, 2012; Kusumastuti, 2008). To produce edible oil, the non-oil fraction must be removed (Bimbo, 1998) by conducting treatment stages, namely degumming, neutralization and bleaching (Yulianti et al., 2011).

The bleaching process in commercial cooking oil manufacture generally uses bleaching earth as an adsorbent. It aims to absorb undesirable colors such as red (Puspasari, 2004). The amount of adsorbent used in the bleaching process varies depending on the type of oil, the intensity of the oil color, and the desired color of the bleached oil (Pedro, et al., 2013). The lemuru fish treatment byproduct characteristic exhibits a fluctuating amount of saturated fatty acids. The treatment used a variety of bleach such as $5 \%$ activated charcoal and zeolite (Astutik, 2012), and 5\% bentonite (Saraswati, 2013). Bentonite with a 5\% concentration is effective in improving the physical and chemical quality of rice bran oil (Indahini, 2011), used cooking oil (Mahditiara, 2002; Andini, 2007), and patchouli oil (Fatimah, 2007). The bleaching process utilized $25 \% \mathrm{HCl}$ activated zeolite at $15 \%$ weight of oil (Ahmadi, 2007). Bleach material, in the form of clay, activated at $90^{\circ} \mathrm{C}$ at $5 \%$ of the weight of oil for 60 minutes (Pedro et al., 2013) These processes is able to improve the quality of fish oil byproducts from the lemuru milling process.

Therefore it is necessary to test three types of adsorbents with different concentrations at the fish oil bleaching stage. It is conducted in order to obtain fish oil quality adhering to quality standards. This study examines the administration of bentonite, zeolite and activated charcoal with different concentrations to bleach tuna fishmeal industry byproduct. In this study, it is expected to obtain the right type of bleaching agent and concentration to improve the fish oil quality from tuna fishmeal industry waste treatment.

\section{MATERIALS AND METHODS OF RESEARCH}

The materials used in this study were raw materials and chemicals. The raw material used was the liquid waste of the Tuna Madidihang (Thunnus albacares) fishmeal industry. The liquid waste was obtained from the Muncar-Banyuwangi, East Java. The 60 mesh activated zeolite and charcoal 60 mesh was obtained from CV. Makmur Sejati. The activated Bentonite was obtained from CV. Sari Kimia.

The chemicals used were $0.1 \mathrm{~N} \mathrm{NaOH}, 96 \%$ alcohol, phenolphthalein indicator, ammonium thiocyanate, $\mathrm{BaCl}_{2}$, ferrous sulfate, $37 \% \mathrm{HCL}, \mathrm{FeCl}_{3} 6 \mathrm{H}_{2} \mathrm{O}, 10 \mathrm{~N} \mathrm{HCL}, \mathrm{H}_{2} \mathrm{O}_{2}$, benzene, methanol, and aquades. The materials used composition analysis of the fatty acids were methylene chloride, $\mathrm{NaOH} 0.5 \mathrm{~N}, 14 \% \mathrm{BF}_{3}$, hexane, and aquades.

The equipment used was the analytical scale "Denver Instrument M 310", Magnetic stirrer, thermometer, centrifugation equipment (Thermo Scientific / SL 40), freezer "GEA", 20D Plus "LaboMed" spectrophotometer, Color reader (Minolta CR 300) and tools glassware. The tools used for analyzing the composition of fatty acids are GC-MS "Shimadzu QP2010S, AGILENT column DB-1, length $30 \mathrm{~m}$, helium carrier gas, ionizing El $70 \mathrm{Ev}$, pressure 12.0 $\mathrm{kPa}$, column flow $0.54 \mathrm{ml} / \mathrm{min}$, linear velocity $26.6 \mathrm{~cm} / \mathrm{sec}$ ".

The experiment was designed using a completely randomized design with 2 factors factorial pattern with 3 replications. The factor I was absorbent type: Zeolite, Bentonite and Active Charcoal. Factor II is an adsorbent concentration level which consists of 3 levels: $5 \%$, $10 \%$, and $15 \%$. Data analysis was performed using analysis of variance (ANOVA) and BNJ $5 \%$.

The adsorbents used in this study were active bentonite, active zeolite and activated charcoal. These three types of adsorbents are activated and in the form of powder with a particle size of 60-100 mesh. The bentonites were brownish yellow, zeolite was white, and activated charcoal was black. The adsorbents were dried using an oven to reduce the water content.

The bleaching process was carried out by weighing fish oil after neutralization, then heating it to a temperature of $80^{\circ} \mathrm{C}$ for 15 minutes, after which the active ingredients and concentration were added according to treatment. Treatment utilizing adsorbent was 
conducted by stirring the fish oil mixture for 20 minutes at $80^{\circ} \mathrm{C}$ using a magnetic stirrer. Furthermore, the mixture of oil and adsorbent was separated by the centrifugation process at a speed of $10,000 \mathrm{rpm}$ for 10 minutes at room temperature $\left( \pm 29^{\circ} \mathrm{C}\right)$ to obtain pure oil.

The refined oil was analyzed to determine its characteristics, including clarity analysis using the color rider method (Huang, 2008), free fatty acids (AOAC, 2006), the level of oxidation based on peroxide values (Kim, 2005) and the composition of fish oil fatty acids with GCMS from the best treatment uses the methylation method (Park and Goin, 1994).

\section{RESULTS AND DISCUSSION}

After the side product of the oil has undergone a degumming and neutralization process, the bleaching process using an adsorbent was conducted. The function of the adsorbent in the bleaching process is to absorb unwanted impurities such as metals and water. In addition to oil degradation products, phosphatides, and excess phosphoric acid are found in oil after the degumming process.

Based on the experiment result, it exhibited that the average level of oil clarity from the bleaching oil byproduct was 30.83 - 36.50. On the other hand, the oil clarity level before bleaching was 26.00. This exhibited that bleaching utilizing bentonite, zeolite and activated charcoal with a concentration level of $5 \%, 10 \%$, and $15 \%$ can increase the clarity level of fish oil from tuna fishmeal byproduct. Analysis of variance exhibited that the type and concentration of adsorbents and their interactions have a significant effect $(\alpha=0.05)$ on the clarity level of fish oil as a by-product of the tuna fishmeal industry (Table 1).

Table 1 - Effect of adsorbent type and concentration on average $L$ value (clarity)

\begin{tabular}{|c|c|c|c|c|c|}
\hline \multicolumn{5}{|c|}{ Fish Oil from Fishmeal Industry Waste } & \multirow{2}{*}{ Commercial Oil } \\
\hline Adsorbent Type & Concentration (\%) & Average L Va & rity) & BNJ $5 \%$ & \\
\hline \multirow{3}{*}{ Bentonite } & 5 & $32.64 \pm 0.42$ & $a b c$ & & \\
\hline & 10 & $33.06 \pm 0.16$ & bc & & \\
\hline & 15 & $31.19 \pm 1.11$ & $a b$ & & \\
\hline \multirow{3}{*}{ Zeolites } & 5 & $32.47 \pm 0.71$ & $a b c$ & & \\
\hline & 10 & $36.50 \pm 1.70$ & $d$ & 2.857 & $35.77 \pm 0.52$ \\
\hline & 15 & $31.74 \pm 0.69$ & $a b$ & & \\
\hline \multirow{3}{*}{ Active Charcoal } & 5 & $30.83 \pm 0.60$ & $\mathrm{a}$ & & \\
\hline & 10 & $34.42 \pm 0.42$ & $c d$ & & \\
\hline & 15 & $29.93 \pm 0.21$ & $\mathrm{a}$ & & \\
\hline
\end{tabular}

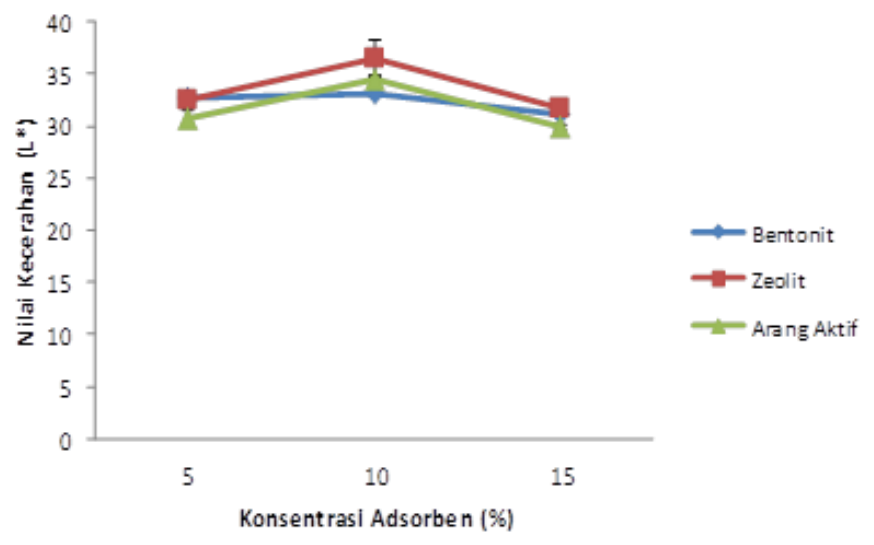

Figure 1 - Fish Oil L value (clarity level) from tuna fishmeal industry waste

Figure 1 illustrates the addition of zeolite adsorbent at $10 \%$ concentration. It can increase the clarity of fish oil better than bentonite and activated charcoal. The ability of zeolites to absorb impurities is higher compared to bentonite and activated charcoal.

The zeolites possess polar characteristics, unlike the other two adsorbents. The $\mathrm{SiO}_{2}$ content is greater compared to bentonite and activated charcoal. According to Zhu et al. 
(1994), the factors influencing the adsorption power is $\mathrm{SiO}_{2}$. The less $\mathrm{SiO}_{2}$ in the adsorbent, the smaller the absorption capacity will be, and vice versa (Syuhada et al., 2008).

The zeolite adsorbent produced the highest oil clarity level compared to bentonite and activated charcoal. The zeolite possesses polar characteristic, hence it possesses a better ability to absorb polar compounds in the oil and increased clarity. White (1991) and Rukmini (2000) stated that silica gel is effective in adsorbing polar components from oil.

The fish oil from fishmeal industrial waste possesses the average ALB of oil due to the treatment of adsorbent types at various concentrations ranged from $0.13-0.23 \%$ (oleate). This value has decreased when compared to the oil before bleaching which is $0.13 \%$ (Oleate). The range of ALB values obtained after all treatments bleaching process has met the standard set by IFOS, which is less than 1\% (oleate). The decrease in the ALB value at the bleaching stage is caused by the reduced water content in the oil. This is in accordance with research conducted by Pedro et al., (2013) that adsorbents can reduce the water content in fish oil which is one of the causes of oil hydrolysis, reducing the number of acids and free fatty acids formed.

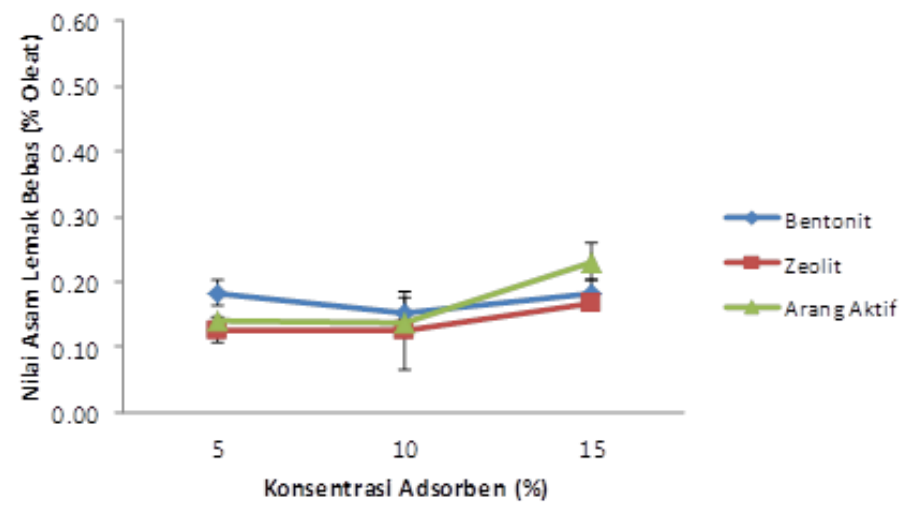

Figure 2 - Levels of fish oil free fatty acids from tuna fishmeal industry waste

The type and concentration of adsorbent have no significant effect on the value of fish oil free fatty acids from tuna fishmeal industry waste. Figure 2 illustrates the fish oil from the waste bleached with the adsorbent. It exhibited the lowest ALB value at a $10 \%$ concentration of each type of adsorbent. The adsorbent can absorb the maximum oxidizing compounds at that concentration. Due to differences in the bleached oil quality, the fish oil quality may vary. Good quality pre-bleached byproduct oil encourages adsorbent works to optimally at a concentration of $10 \%$. Administering excessive concentrations will lead to suboptimal adsorbent performance, increasing the oil ALB. Vaisya and Gupta (2002) state a large amount of adsorbent administered would reduce the surface area of the adsorbent to interact with the adsorbate. Estiasih (2009) stated that the amount of adsorbent used in the bleaching process depends on the type of oil, the intensity of the oil color, and the desired color of the bleached oil.

Bentonite, zeolite and activated charcoal can prevent oxidation. It prevents aldehydes, organic acids, and ketones formation in oil (Fatimah, 2007; Ahmadi and Mushollaeni, 2007; Chandra, 2009; Ghani, 2014). In this study, the lowest ALB was obtained from the use of zeolite adsorbents. The zeolites can bind water and acids compared to bentonite and activated charcoal. By binding water and acids, the hydrolysis occurrence can be minimized. Pedro et al., (2013) states that water and acid in fish oil cause oil hydrolysis. The oil would undergo oxidation and increased acid value.

The ability of zeolites to reduce ALB is better than bentonite and activated charcoal. The zeolites have the ability to absorb better compared to other adsorbents. The zeolites possess more silica (Si) element; therefore its ability to bind free fatty acids is greater than bentonite and activated charcoal. Chapman and Pankoch (1992); Sutarti (1994); Proctor et al. (2005) stated that the Si element is capable of binding free fatty acids to form Si free fatty 
acids complex compounds. This process occurs because of the formation of hydrogen bonds between the silicate and the surface of free fatty acids.

Determination of the peroxide value aimed to determine the level of fish oil damage. The peroxide value is a measure of the peroxide and hydroperoxide levels formed in the initial stages of a fat oxidation reaction. The presence of peroxides and aldehydes, which are the result of primary and secondary oxidation from the oil, can indicate the degree of oil damage (Hammond et al., 2005; Raharjo, 2008). The average peroxide value due to the treatment of adsorbent types at various concentrations ranged from 2.12-6.85 meq/ $/ \mathrm{kg}$, where the overall value of the peroxide value after bleaching has decreased compared to prebleaching byproduct oil at $7.10 \mathrm{meq} / \mathrm{kg}$.

Fish oil contains heme pigment, a part of hemoglobin and myoglobin. The pigment contains Fe mineral metal which can stimulate oxidation (Winarno, 2004). The treatment using adsorbents in the bleaching process can reduce the peroxide value in fish oil. This is consistent with the function of the adsorbent, which is removing impurities, pigments, oxidation products, metals as catalyst compounds, and sulfur compounds. Removing impurities, metals and oxidation can improve the quality and oxidative stability of fish oil (Rossi et al., 2003).

Results of the analysis of variance exhibited that the type and concentration of adsorbent had a significant effect $(\alpha=0.05)$ on the average peroxide value. The interaction between the types and concentration of the adsorbent had a significant effect $(\alpha=0.05)$ on the peroxide value in each soil type (Table 2).

Several factors, namely the presence of oxygen, peroxidase enzymes, heat, radiation (light), and monovalent ions can accelerate oil oxidation (Kusnandar, 2001). The high peroxide value of fishmeal industry waste is caused by the fishmeal oil high unsaturated fatty acid content. According to Huss (1998), unsaturated fatty acids content in fish oil can stimulate oxidative damage.

Table 2 - Effect of adsorbents type and concentration on the average peroxide value

\begin{tabular}{|c|c|c|c|c|c|c|c|}
\hline \multicolumn{5}{|c|}{ Fishmeal Oil Byproduct } & \multicolumn{3}{|c|}{ Quality Standard } \\
\hline Adsorbent Type & Concentration (\%) & \multicolumn{2}{|c|}{ Average peroxide value Value(Meq/kg) } & BNJ $5 \%$ & \multirow[t]{2}{*}{ IFOMA } & \multirow[t]{2}{*}{$\begin{array}{l}\text { Draf } \\
\text { CAC }\end{array}$} & IFOS \\
\hline & 5 & $6.88 \pm 0.06$ & $\mathrm{a}$ & & & & \\
\hline \multirow[t]{3}{*}{ Bentonite } & 10 & $5.81 \pm 0.03$ & $d$ & & & & \\
\hline & 15 & $6.03 \pm 0.13$ & $\mathrm{bc}$ & & & & \\
\hline & 5 & $3.45 \pm 0.67$ & $a b$ & & & & \\
\hline \multirow[t]{3}{*}{ Zeolite } & 10 & $2.12 \pm 0.31$ & e & 1.319 & $3-20$ & $<5$ & $<5$ \\
\hline & 15 & $5.71 \pm 0.14$ & $\mathrm{~cd}$ & & & & \\
\hline & 5 & $4.45 \pm 0.03$ & $\mathrm{a}$ & & & & \\
\hline \multirow[t]{2}{*}{ Activated Charcoal } & 10 & $2.37 \pm 0.02$ & a & & & & \\
\hline & 15 & $6.85 \pm 0.36$ & a & & & & \\
\hline
\end{tabular}

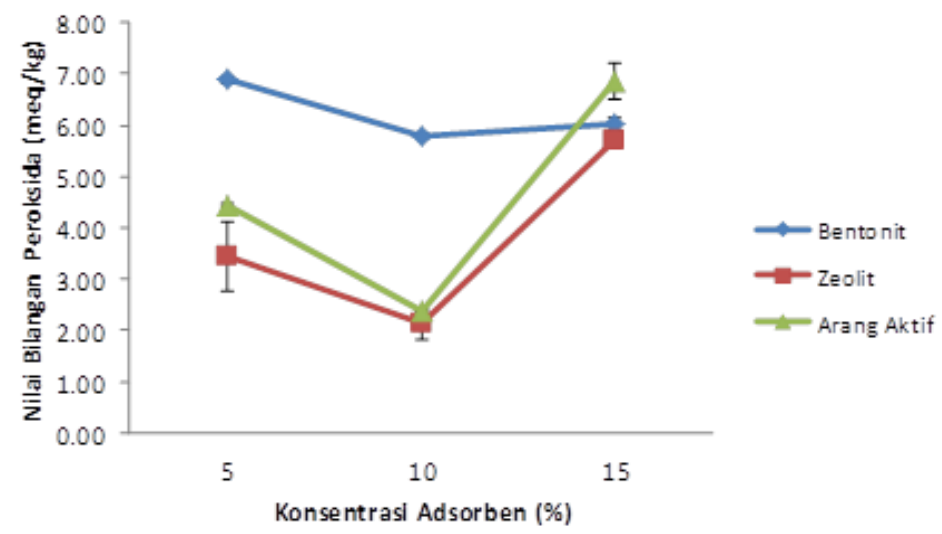

Figure 3 - Fish oil peroxide value from tuna fishmeal industry byproduct

The range of peroxide values obtained after bleaching all treatments has met the standards set by the International Fish Oil Standard (IFOS), which is less than $5 \mathrm{meq} / \mathrm{kg}$. The 
fish oil byproduct (Figure 3) were bleached using adsorbent. The 10\% concentration of each adsorbent type exhibited the lowest peroxide value, due to its capability to absorb oxidizing compounds. The adsorbent administration reduces the pigment component, free fatty acids and other impurities present in oil (Suseno et al., 2011). A high adsorbent concentration allows maximum impurities absorption. However, this causes the natural antioxidants contained in the absorbed pigment to affect the fish oil oxidation stability. Patterson (2009) states that the treatment process using bleaching soil can absorb up to half the oil content natural antioxidant.

In this study, zeolite was able to lower the value of the peroxide value due to its ability to absorb impurities and free fatty acids. Holmes (1994) states that zeolites are minerals consisting of hydrated aluminosilicate crystals that contain soil alkaline or alkaline cations in three-dimensional value. The metal ions can be replaced by fabric cations without damaging the zeolite structure and can absorb in a reversible manner. This may also be caused by the relatively large oil molecules being split into radicals or smaller molecules in the form of aldehydes and / or alkanoates. These compounds have polar groups, therefore these can interact or bond with zeolites. Kusumastuti (2004) stated that the use of a $10 \%$ zeolite concentration can reduce the peroxide value due to the zeolite polarity.

In general, the use of bentonite, zeolite and activated charcoal at various levels of concentration can improve the oil quality. Bentonite and zeolite are bleaching earth possessing a three-layered structure that allows triglyceride molecules to be absorbed through interactions with active $\mathrm{H}^{+}$ions on surfaces contained in both bentonite and zeolite structures (Neuman and Dunford 2004). The best sample in this study was obtained from tuna fishmeal industrial waste fish oil byproduct administered with bleaching treatment using $10 \%$ zeolite adsorbents concentration. After the bleaching process, the oil clarity level obtained was 36.50 , the ALB level was $0.13 \%$ (oleate), and the peroxide value was 2.12 $\mathrm{meq} / \mathrm{kg}$. The resulting parameter values meet the fish oil quality standard requirements (IFOS).

Analysis of fatty acid composition was conducted on the best-bleached fish oil. This analysis aimed to determine the composition of fatty acids contained in fish oil after the bleaching process. Chromatogram of the bleached fatty acid composition of fish oil is presented in Figure 4.

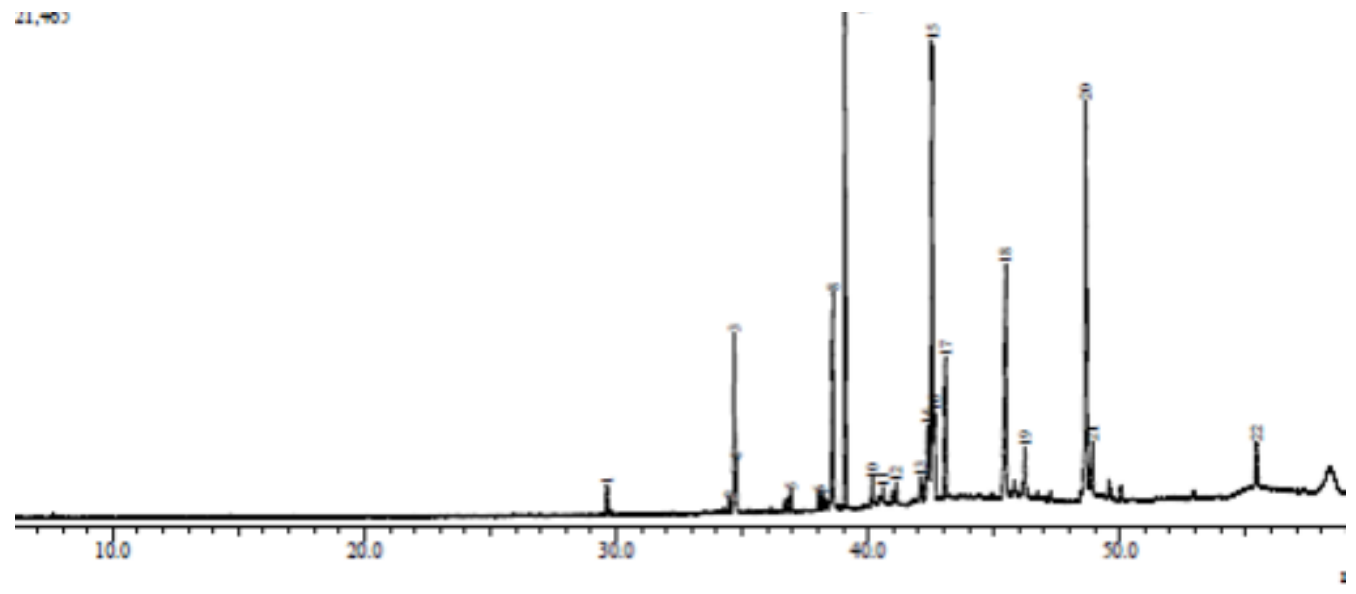

Figure 4 - Chromatogram of the fatty acids compositions in the bleached fish oil (bleaching)

Table 3 exhibited the amount of Saturated Fatty Acids (SFA) in byproduct oil after the bleaching process is $36.19 \%$. The dominating type of fatty acid is palmitic acid at $26.63 \%$. The composition of unsaturated fatty acids with a one double bond (MUFA, Monounsaturated Fatty Acid) in byproduct oil at this treatment stage is $29.73 \%$. The type of fatty acid that dominates in the composition of monounsaturated fatty acids is oleic acid at $20.18 \%$. The amount of EPA (C20: $5 \omega-3)$ and DHA (C22: $6 \omega-3)$ in fish oil from tuna fishmeal industrial waste was $12.03 \%$ and $18.25 \%$ respectively. 
Table 3 - Composition of fatty acids in bleached fish oil (bleaching)

\begin{tabular}{|c|c|}
\hline Fatty Acid Types & Total / Composition (\%) \\
\hline C14: 0 (Myristic) & 6.5 \\
\hline C15: 0 (Pentadeclic) & 0.57 \\
\hline C16: 0 (Palmitate) & 23.63 \\
\hline C17: 0 (Margarat) & 0.61 \\
\hline C18: 0 (Stearic) & 4.88 \\
\hline C16: $1 \omega-7$ (Palmitoleate) & 7.76 \\
\hline C16: $3 \omega-3$ (Hexadecatrienoic) & 0.35 \\
\hline C18: $1 \omega-9$ (Oleat) & 20.18 \\
\hline C18: $2 \omega-6.9$ (Linoleic) & 6.92 \\
\hline C18: $3 \omega-3$ ( $a$-linolenic) & 0.63 \\
\hline C20: $1 \omega-9$ (eicosenoate) & 1.79 \\
\hline $\mathrm{C} 20: 5 \omega-3$ (EPA) & 12.03 \\
\hline $\mathrm{C} 22: 6 \omega-3(\mathrm{DHA})$ & 18.25 \\
\hline SFA & 36.19 \\
\hline MUFA & 29.73 \\
\hline PUFA & 34.08 \\
\hline MUFA + PUFA & 63.81 \\
\hline
\end{tabular}

The composition of unsaturated fatty acids with more than one double bond (PUFA, Polyunsaturated Fatty Acid) in industrial waste fish oil is $32.08 \%$. The composition of total unsaturated fatty acids (MUFA + PUFA) is $61.81 \%$. Omega-3 fatty acids are the most important fatty acids for health.

\section{CONCLUSION}

The use of bentonite, zeolite and activated charcoal at various levels of concentration in each of the adsorbents can improve the oil quality. The interaction between adsorbent type and concentration has a significant effect on the level of clarity ( $L$ value) and peroxide value. It exhibited an insignificant effect on free fatty acid (ALB) levels. The best treatment of fish oil treatment from the MHS treatment was $10 \%$ zeolite adsorbent concentration. It exhibited an average value of $L * 36.50$, ALB content $0.17 \%$ (oleate), and the peroxide value 2.12 meq / $\mathrm{kg}$. The composition of fatty acids from the byproduct oil was $36.19 \%$ SFA, $29.73 \%$ MUFA, $34.08 \%$ PUFA and $63.81 \%$ total unsaturated fatty acids (MUFA + PUFA). Therefore fish oil from tuna fishmeal industry waste can be considered as a source of unsaturated fatty acids (PUFA) especially EPA and DHA.

\section{REFERENCES}

1. Abdillah H. M. 2008. Pemurnian Minyak dari Limbah Pengolahan Ikan. Skripsi. IPB. Bogor.

2. Ahmadi K., Mushollaeni W. 2007. Aktivasi Kimia Zeolit Alam untuk Pemurnian Minyak Ikan dari Hasil Samping Penepungan Ikan Lemuru (Sardinella longicepa). Jurnal Teknologi pertanian. Vol. 8 No. 2. pp. 71-79.

3. Ahmadi K. 2009. Pemurnian minyak ikan hasil samping penepungan ikan lemuru (Sardinella longiceps) menggunakan zeolit alam teraktivasi. UPN Jatim Repository. 1(1): 93-102.

4. Akoh C. and David, B. Min. 1998. Food Lipid Chemistry, Nutrition, and Biotechnology. Marcel Dekker. New York.

5. Aidos I. 2002. Production of High-Quality Fish Oil from Herring Byproducts. Ph.D. Thesis, Wageningen University, The Netherlands.

6. Andini D.F.V. 2007. Penjernihan Minyak Bekas Penggorengan Vakum Keripik Buah Apel dengan Berbagai Jenis and Konsentrasi Adsorben. Skripsi. Universitas Brawijaya. Malang.

7. AOAC. 1995. Official Methods of Analysis of The Association of Official Analytical Chemists. AOAC Int., Washington. 
8. Astutik S. 2012. Pengaruh Variasi Bahan Pemucat Terhadap Karakteristik Fisika, Kimia and Komposisi Asam Lemak Minyak Hasil Pemurnian Limbah Penepungan Ikan. Skripsi. Universitas Jember. Jember.

9. Bimbo AP. 1998. Guidelines for characterizing food-grade fish oil. INFORM. International News on Fats, Oils and Related Material. Vol 9,number 5.pp 473-483.

10. Crexi, V.T. et al, 2010. Production and Refinement of Oil from Carp (Cyprinus carpio) Viscera. Food Chemistry, 119 (1): 945-950.

11. Estiasih T., Ahmadi, K., Nisa, C.N. and Kusumastuti, F. 2009. Optimasi Kondisi Pemurnian Asam Lemak Omega-3 Dari Minyak Hasil Samping Penepungan Tuna (Thunnus sp) dengan Kristalisasi Urea. Jurnal Teknologi and Industri Pangan. Vol. XX no. 3.

12. Feryana, I. W., Suseno, H. S \& Nurjanah. 2014. Pemurnian Minyak Ikan Makerel Hasil Samping Penepungan dengan Netralisasi Alkali. Jurnal Pengolahan Hasil Perikanan Indonesia, 17 (3): 207-214.

13. Hilder M.H. 1997. 'Oil Storage, Transport and Handling'. Dalam Gunstone, F.D and F.B. Padley (ed). Lipid Technologies and applications. Marcel Decker. Inc. New York.

14. Indahini D. 2011. Pengaruh Jenis and Konsentrasi Adsorben pada Proses Pemucatan terhadap Sifat Fisik and Kimia Minyak Bekatul Padi. Skripsi. Universitas Brawijaya. Malang.

15. Kusumastuti F. 2008. Optimasi Kristalisasi Urea Pada Pembuatan Konsentrat Asam lemak Omega-3 dari Minyak Hasil Samping Penepungan Ikan Tuna (Thunnus sp). Skripsi. Universitas Brawijaya. Malang.

16. Lianawati W. 2000. Studi Mikroenkapsulasi Minyak Ikan Hasil Samping Penepungan Tuna (Tuna Precook Oil). Tesis. IPB. Bogor.

17. Neuman TE. and Dunford NT. 2004. 'Edible Oil Bleaching'. Dalam Dunford NT and Dunford HB (Ed.). Nutritionally Enhanced Edible Oil and Oilseed Processing. AOAC. Publishing.

18. Panagan AT., Hanity and Jujur VG. 2011. Analisis Kualitatif and Kuantitatif Asam lemak Tak Jenuh Omega-3 dari Minyak Ikan Patin (Pangasius) dengan Metode Kromatografi Gas. J. Penelitian Sains. 14 (4C) : 38-42.

19. Palanisamy UD., Sivanathan M, Radhakrishanan AK., Haleagrahara N., Subramaniam T., and Chiew GS. 2011. An Effective Ostrich Oil Bleaching Technique Using Peroxide Value an Indicator. J. Molecules. 16:5709-5719.

20. Park P.W. and R.E. Goins. 1994. In Situ Preparation of Fatty Acids Methyl Ester for Analysis of Fatty Acids Composition in Food. J.Food Sci. 59:1262-1266.

21. Pedro J. Garcia-Moreno, Antonio Gudix, Luis Gomes-Robledo, Manuel Melgosa, and Emilia M. Guandix. 2003. Optimization of Bleaching Conditions for Sardine Oil. Journal of Food Engineering. 116: 606-612.

22. Purnomo E. 2005. Pemanfaatan Bahan Sisa Sebagai Upaya Minimasi Limbah Padat. Tesis. Magister Ilmu Lingkungan. Universitas Diponogoro. Semarang.

23. Rossy A., 1998. Studi Mikroenkapsulasi and Stabilitas Minyak Kaya Asam Lemak Omega-3 dari Limbah Minyak Penepungan Ikan Tuna (Tuna Precook Oil). IPB Press.

24. Vaisya C.R and Gupta, K.S. 2002. Modeling Arsenic (III) Adsorption from Water by Sulfate-Modified. Iron Coated Sand (SMIOCS). Journal of Chemical Technology and Biotechnology. Vol. 78.

25. Wardhani A.P. 2012. Optimasi Kristalisasi Pelarut Suhu Rendah pada Proses pembuatan Konsentrat Asam Lemak $\omega-3$ dari Minyak Hasil Samping Penepungan Ikan Tuna (Thunnus sp). Skripsi. Jurusan Teknologi Hasil Pertanian, Fakultas teknologi Pertanian, Universitas Brawijaya. Malang.

26. Winarno F.G. 1993. Kimia Pangan and Gizi. Gramedia Pustaka Utama. Jakarta.

27. Yulianti E., Nova D.P., Romaidi and Gahanim F. 2011. Pengaruh Konsentrasi NaOH Pada Proses Netralisasi Minyak Ikan Hasil Samping Industri Penepungan Ikan Terhadap Asam Lemak Bebas (Free Fatty Acid) and Komposisi Asam-asam Lemak Tidak Jenuh. Jurusan Kimia Fakultas Sains and Teknologi Universitas Islam Negeri Maulana Malik Ibrahim Malang. 